\title{
Enterprise interoperability: information, services and processes for the interoperable economy and society
}

\author{
Erwin Folmer • Marten van Sinderen • \\ Paul Oude Luttighuis
}

Published online: 23 April 2014

(C) Springer-Verlag Berlin Heidelberg 2014

Networked business models are becoming an indisputable reality in today's economy (Legner and Lebreton 2007), and a recent Capgemini study concludes that companies need to "significantly increase their degree of collaboration as well as their networking capability" in order to be competitive and successful in the future (Falge et al. 2012). Hence, there is a development and drive towards an interoperable economy and society, affecting companies and their information, services and processes. Modern companies need a 'quality' referred to as enterprise interoperability, and here defined as" the ability to affect each other's operation in a defined way and, through this, to positively contribute to their own and each other's business objectives" (van Sinderen et al. 2013). This definition builds on the general IEEE definition of system interoperability ("the ability of two or more systems to exchange information and to use the information that has been exchanged", IEEE 1990), but emphasizes that interoperability must be meaningful and useful for the enterprises involved.

Enterprise interoperability may be seen positioned at the crossroads of two major trends, both of them happening for two decades now.

First, with the ever increasing use of information systems inside enterprises, the enterprise itself, its goals, its value streams, its processes, its information, and other assets are more and more conceived as design objects themselves. Enterprise design is an established discipline now, both in the commercial and in the scientific community, although challenges remain to master the complexity of modern

\footnotetext{
E. Folmer ( $\square)$

TNO, Enschede, The Netherlands

e-mail: erwin.folmer@tno.nl

E. Folmer · M. van Sinderen

University of Twente, Enschede, The Netherlands

P. Oude Luttighuis

Le Blanc Advies, Apeldoorn, The Netherlands
} 
enterprises (Dietz et al. 2013). Much of the complexity involved arises from the combination of the inherently social and economic aspects of enterprises on one hand, and the inherently analytical and technical aspects of design on the other. There is however also an important resemblance between these two sides: both generally involve a need for mastering — and sometimes controlling - complexity. As much as management is about mastering an enterprise, design is about mastering system complexity.

The second trend concerns the ICT-enabled transgression of business processes across the operational borders of individual organizational units (Keil et al. 2001), thus challenging classical hierarchical arrangements inside enterprises and introducing horizontal co-ordination (Chen et al. 2008). There is no doubt that this trend increases the complexity of enterprises and their information systems. Hierarchical arrangements are a popular way of dealing with complexity, both in management and in design, but inter- and intra-organizational co-operation challenge hierarchy. Both managers and designers therefore have to find other ways of dealing with complexity. This is how the originally unmistakably technical term interoperability has found its way into the enterprise arena (Ducq et al. 2004).

How can enterprises, and their information systems, be designed and managed in such a way that they can deal with horizontal operational co-operations? Because of the inherent additional complexity, this area inevitably proves to be a particularly challenging area of innovation and research. As a consequence, many interoperability frameworks emerged, aiming at structuring the overall problem of enterprise interoperability and positioning and aligning efforts to overcome the problem (van Sinderen et al. 2013). For example, the Future Internet Enterprise Systems (FInES) Standardization Task Force identified eight architectural frameworks for enterprise interoperability, which all agree on the dimensions of interoperability barrier and interoperability concern, but nonetheless incorporate various ways of addressing interoperability (Pattenden et al. 2012). This leads us to conclude that the maturity of the enterprise interoperability discipline still does not match the importance attached to it by many (Oude Luttighuis and Folmer 2011), both academically and business-wise.

Academic research and innovation into the enterprise interoperability area is accompanied by a series of conferences contributing to the interaction of researchers and practitioners in the field. This special issue on Enterprise Interoperability springs from the 2013 International IFIP Working Conference on Enterprise Interoperability (IWEI), held in Enschede, the Netherlands, in March 2013. A selection of the best papers presented at this conference was invited to be revised and extended to a journal paper. Finally, five papers were accepted to this special issue, each dealing with specific ways of mastering the inherent complexity involved in enterprise interoperability.

Two papers deal with standardization, a measure aimed at controlling complexity by reducing the ever-growing variety inside and across organizations. As it goes, even when standards are being designed, so many of them arise that standards selection becomes a complicated problem in its own right (Otto et al. 2011). In Fit for Purpose: Engineering Principles for Selecting an Appropriate Type of Data Exchange Standard, Rosenthal et al. present their research in helping enterprises to 
select appropriate data exchange standards in a way that matches the characteristics of the interoperability problem at hand. Also, in case such a standard is used for dealing with a given interoperability issue, its quality is an important determinant of its success. Such quality, however, may not only be used as a criterion for selecting among standards, it is also an important measure for those who are responsible for designing, managing, and marketing the standard. In Data Standards Quality Measured for Achieving Enterprise Interoperability: The Case of the SETU Standard for Flexible Staffing, Folmer et al. discuss a case study of standards quality measurement and control, in the temporary labor industry.

The other three papers can all be positioned in the area of enterprise architecture. Enterprise architecture has been positioned as the discipline par excellence that aligns the deployment of information systems with business requirements. So, it is where the social and economic aspects meet design and technology. Especially where horizontal co-operations come into play, imperative co-ordination seems to be less applicable, because it so severely restricts the actions of all involved. Instead, more declarative approaches come to mind, that do not deal with how processes should act, but what they should accomplish. One of these approaches is business rule management. In Defining Collaborative Business Rules Management Solutions: Framework and Method, Zoet and Versendaal show how to have a given business rule management solution fit with an enterprise's value proposition.

Another complexity control technique dealt with in this special issue is prediction. In order to make sure whether a given enterprise interoperability solution meets the business requirements, prediction techniques may prove helpful. In A method for predicting the probability of business network profitability, Johnson et al. show how such techniques may be used for predicting the profitability of an enterprise network. The framework on which this work is based, is elaborated on in An Architecture Modeling Framework for Probabilistic Prediction, of Johnson et al.

We hope that this special issue will inspire researchers and practitioners in devising and testing new and useful ways for the enterprise interoperability problem solver to do his/her job. From a management perspective, such ways are needed, as one cannot afford to pass the buck of design and technology problems to others: the interoperability knife cuts right through all the layers, from strategy right down to infrastructure. From a design perspective, these ways would allow designers to be as much familiar with designing the complex relations inherent in enterprise interoperability, as they are today with sub-ordination techniques such as classification, encapsulation, and stratification for software and complex systems engineering (Parnas 1972; Oliver et al. 1997).

We like to thank the authors for their efforts in writing and revising their papers, and the reviewers for their commitment in reviewing the papers and providing the authors with constructive feedback. We also like to take the opportunity to thank the editors and the editorial office of the ISeB journal for the excellent collaboration during all stages of preparing this special issue. 


\section{References}

Chen D, Doumeingts G, Vernadat F (2008) Architectures for enterprise integration and interoperability: past, present and future. Comput Ind 59(7):647-659

Dietz JLG, Hoogervorst JAP, Albani A et al (2013) The discipline of enterprise engineering. Int J Organ Des Eng 3(1):86-114

Ducq Y, Chen D, Vallespir B (2004) Interoperability in enterprise modelling: requirements and roadmap. Adv Eng Inform 18(4):193-203

Falge C, Otto B, Österle H (2012) Data quality requirements of collaborative business processes. In: 45th Hawaii International Conference on System Sciences (HICSS), IEEE Computer Society, pp. 4316-4325

IEEE (1990) IEEE Standard Glossary of Software Engineering Terminology. IEEE Std 610.12-1990. New York: IEEE Computer Society

Keil T, Eloranta E, Holström J et al (2001) Information and communication technology drives business transformation - a call for research. Comput Ind 44(3):263-282

Legner C, Lebreton B (2007) Preface to the focus theme section: 'Business Interoperability'-business interoperability research: present achievements and upcoming challenges. Electron Mark 17(3):176-186

Oliver DW, Kelliher TP, Keegan JG Jr (1997) Engineering complex systems with models and objects. McGraw-Hill, New York

Otto B, Folmer E, Ebner V (2011) A characteristics framework for semantic information systems standards. ISeB 10(4):571-602

Oude Luttighuis P, Folmer E (2011) Equipping the enterprise interoperability problem solver. In: Charalabidis $\mathrm{Y}$ (ed) Interoperability in digital public services and administration: bridging E-Government and E-Business. IGI Global, pp. 339-354

Parnas DL (1972) On the criteria to be used in decomposing systems into modules. Commun ACM 15(12): $1053-1058$

Pattenden S, Young R, Zelm M. (2012). Future Internet Enterprise Systems (FInES) Standardisation Task Force Report-Working Draft (second Edition). http://www.fines-cluster.eu/jm/Documents/Downloaddocument/298-FInES-Cluster-2012-FInES-Standardisation-Task-Force-Report-Working-Draft-2.html

van Sinderen MJ, Johnson P, Doumeingts G (2013) Interoperability and future internet for nextgeneration enterprises—-special issue editorial and state of the art. Comput Ind 64(8):881-886 